\title{
MATEUSZ SAKOWICZ
}

Dublin

\section{Referendum nad Traktatem Lizbońskim w Irlandii. Analiza politologiczna}

\begin{abstract}
Wstęp
12 czerwca 2008 roku odbyło się w Irlandii referendum nad Traktatem Lizbońskim. Zostało poprzedzone intensywną kampanią, w której poza wiodącymi siłami politycznymi w kraju, wzięły udział nieznane wcześniej ugrupowania oraz stowarzyszenia przeciwne dokumentowi i kontestujące zasady funkcjonowania Unii Europejskiej. Traktat mający w założeniu usprawnić mechanizmy decyzyjne oraz zreformować instytucje Unii Europejskiej został przez Irlandczyków odrzucony - 48\% głosujących oceniło go pozytywnie i dało temu wyraz oddając głos na 'Tak', podczas gdy większość, to jest 52\%, zagłosowało na 'Nie'. Mimo poparcia dla dokumentu ze strony koalicji rządowej na czele z partią Fianna Fail oraz największej partii opozycyjnej Fine Gael, Irlandczycy zagłosowali na przekór politykom wiodących sił politycznych, a zgodnie z oczekiwaniami enigmatycznej formacji nieznanych w większości ugrupowań reprezentujących krytyków dokumentu. Wynik referendum stanowił w dużej mierze zaskoczenie dla rządu premiera Briana Cowena. Z państw członkowskich Unii Europejskiej spłynęła na Irlandię fala krytyki - Traktat odrzucił kraj, który uznawano za modelowy przykład sukcesu we Wspólnotach i którego obywateli postrzegano jako euroentuzjastów. Po tym jak do publicznej wiadomości podano pierwsze rezultaty referendum zarówno irlandzki rząd, jak i Komisja Europejska przystapiły do badań opinii publicznej, czego konsekwencją była publikacja raportów: Flash Eurobarometer, Post-referendum survey in Ireland oraz Post Lisbon Treaty Referendum Research Findings, Millward Brown IMS.

Autor niniejszego opracowania odwołuje się do treści raportów oraz analiz i komentarzy prasowych, starając się odpowiedzieć na pytanie o to jakie przyczyny zadecydowały o odrzuceniu przez Irlandię Traktatu Lizbońskiego oraz jakie są możliwe scenariusze jego ewentualnego przyjęcia przez Irlandię w przyszłości. Autor przyjmuje tezę, że Irlandia podejmie na przestrzeni 2009 roku próbę przeprowadzenia drugiego referendum w sprawie Traktatu Lizbońskiego. Analizuje w związku z tym aktualne stanowisko irlandzkiego rządu, odwołuje się do ocen mediów, nastrojów społecznych oraz komentarzy płynących ze strony innych państw członkowskich UE, w tym sprawującej w drugiej połowie 2009 roku prezydencję Francji.
\end{abstract}

\section{Analiza raportu Eurobarometr przygotowanego na zlecenie Komisji Europejskiej}

Po ogłoszeniu oficjalnych wyników referendum, Instytut Gallupa przystapił do badania Eurobarometr wykonanego na zlecenie reprezentacji Komisji Europejskiej w Irlandii. 
Badanie przeprowadzono na przestrzeni trzech dni - od 13 do 15 czerwca 2008 roku - na losowo wybranej grupie 2000 respondentów powyżej osiemnastego roku życia. Ankieta miała formułę telefoniczną. Główną przesłanką przeprowadzonego badania była odpowiedź na pytania o to jakie przyczyny kierowały osobami, które nie zdecydowały się na uczestnictwo w referendum, jaka była ocena kampanii prowadzonej przez oba obozy, a także ustalenie powodów, które stały za opowiedzeniem się przez głosujących za jedną z opcji. Zleceniodawcy badania starali się również ustalić jak głosujący zareagowali na rezultaty i jak oceniają konsekwencje wyniku referendum.

Rozpatrując społeczny profil osób, które nie głosowały w referendum, nasuwa się konkluzja, że osoby młode były znacznie mniej chętne do wzięcia w nim udziału aniżeli osoby starsze (64\% osób w wieku 18-24 nie zdecydowało się głosować w porównaniu z $31 \%$ osób powyżej 55 roku życia). 51\% pracowników fizycznych nie głosowało. Osoby samozatrudnione oraz niepracujące były natomiast bardziej skłonne głosować - odpowiednio 39\% i 44\% nie zdecydowało się oddać głosu. 86\% respondentów, którzy nie wzięli udziału w referendum wskazało, że są za członkowstwem Irlandii w Unii Europejskiej, podobne stanowisko zajęło $89 \%$ głosujących. W referendum wzięło udział $20 \%$ osób, które nie uczestniczyły w ostatnich wyborach parlamentarnych. Frekwencja była jednak niższa i wyniosła 53\% (w wyborach parlamentarnych było to $67 \%$ ).

Wykres 1. Powody, dla których respondenci nie wzięli udziału w głosowaniu nad Traktatem Lizbońskim w Irlandii
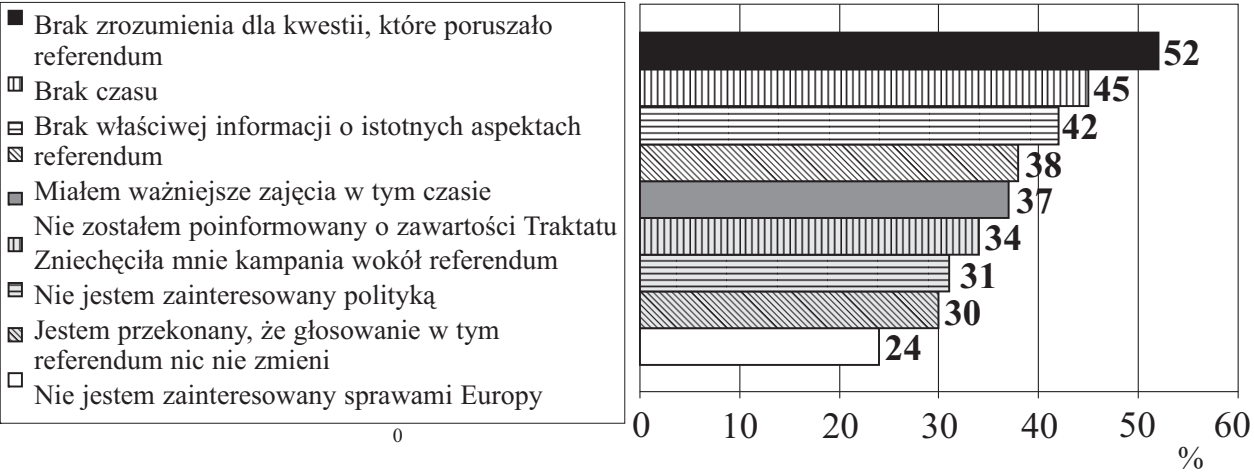

Źródło: Flash Eurobarometer, Post-referendum survey in Ireland, 18.06.2008, s. 3.

Niespełna 30\% głosujących podjęło decyzję o tym za jaką opcją się opowiedzą w momencie ogłoszenia referendum lub krótko po tym. 55\% głosujących określiła swoje stanowisko w ostatnich tygodniach poprzedzających głosowanie. Relatywnie znaczna ilość respondentów wyrobiła sobie zdanie w zakresie dokumentu w trakcie trwania kampanii. $68 \%$ respondentów wskazała, że nie zmieniła zdania o tym jak głosować w trakcie trwania referendum ${ }^{1}$.

Niezależnie od faktu, że sam wynik referendum był wyrównany i ilość głosów oddanych na obie opcje była zbliżona, głębsza analiza wyników wskazuje duże zróżnico-

1 Flash Eurobarometer, Post-referendum survey in Ireland, 18.06.2008, s. 4. 
wanie głosów w poszczególnych grupach społecznych. Jak wcześniej wspomniano, większość osób młodych była zdecydowanie za odrzuceniem Traktatu. Większość kobiet oraz osób niepracujących była także przeciw. Do głównych zwolenników dokumentu należały osoby z wyższych grup społecznych, samozatrudnieni, kadra kierownicza oraz osoby z wyższym wykształceniem.

Wykres 2. Profile głosujących nad Traktatem Lizbońskim w Irlandii

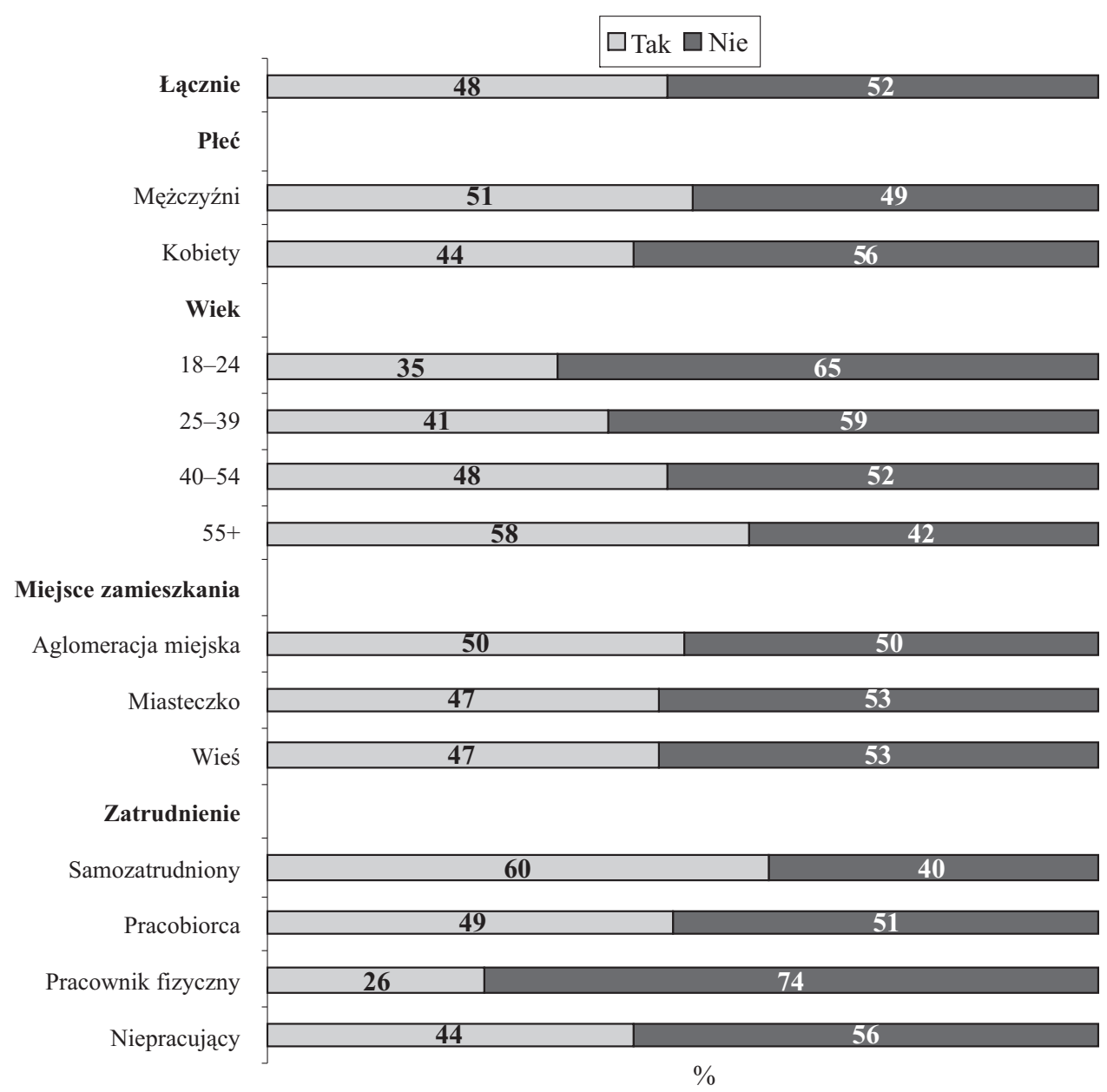

Źródlo: Flash Eurobarometer, Post-referendum survey in Ireland, 18.06.2008, s. 6.

\section{Przyczyny oddania głosu na 'Tak' lub 'Nie'}

W trakcie badania zadano także respondentom pytanie otwarte o powody, dla których zagłosowali na 'Tak' bądź 'Nie'. Ponad 30\% głosujących za Traktatem postapiło tak z powodu przeświadczenia, że jest to najlepsze z punktu widzenia Irlandii. Pozostałe odpowiedzi dotyczyły przede wszystkim korzyści, jakie Irlandia uzyskała i uzy- 
skuje z UE. 9\% głosujących za dokumentem wskazało, że Traktat sprawi, iż pozostanie w pełni zaangażowana w politykę europejską. Kolejne $9 \%$ stało na stanowisku, że ratyfikacja wpłynie pozytywnie na irlandzką gospodarkę. Pozostałe argumenty miały w skali wymienionych charakter marginalny - między innymi pojawiały się opinie, że Traktat sprawiłby, iż proces decyzyjny w Unii Europejskiej byłby bardziej efektywny (5\%) oraz Unia Europejska funkcjonowałaby lepiej na arenie globalnej (4\%).

Głosujący na 'Nie' przedstawili szerokie spektrum przyczyn. Część podkreślała brak dostatecznie jasnych informacji o treści dokumentu (22\%). Kolejnym powodem, który wymieniło $12 \%$ respondentów z tego obozu, była chęć ochrony irlandzkiej tożsamości. Z pozostałych pojawiających się argumentów należy przytoczyć brak zaufania do polityków, chęć ochrony irlandzkiej neutralności oraz zachowanie irlandzkiego komisarza w składzie Komisji Europejskiej, potrzebę ochrony istniejącego systemu podatkowego. Zaledwie 1\% głosujących na 'Nie' wskazał jako przyczynę obawę, iż wprowadzenie dokumentu w życie spowoduje zwiększenie napływu imigrantów do ich kraju.

$80 \%$ głosujących za odrzuceniem Traktatu wyraziło swoje poparcie dla członkostwa Irlandii w Unii Europejskiej. Podobne stanowisko przedstawiło 98\% głosujących na 'Tak'2. Można zatem przyjąć założenie, że panuje społeczny konsensus co do faktu, że Irlandia powinna pozostać w strukturze Unii Europejskiej.

\section{Glówne wnioski podsumowujące badanie}

- Ponad połowa osób, które nie wzięły udziału w referendum wskazała, że postapiło tak z uwagi na brak zrozumienia samego dokumentu; co znamienne, osoby młodsze były mniej zainteresowane wzięciem udziału w referendum aniżeli starsi.

- W głosowaniu na 'Tak' głównym argumentem było przeświadczenie, że Traktat służy interesom Irlandii, pozostałe argumenty były dość jednowymiarowe, skoncentrowane wokół korzyści, jakie Irlandia uzyskała dzięki członkostwu we Wspólnotach.

- Głosujący na 'Nie' prezentowali szersze spektrum argumentów stojących za ich decyzją za główną przyczynę (podkreśliło ją 25\% głosujących na 'Nie') uznali oni fakt, że przygotowania do referendum pozbawione były właściwej kampanii informacyjnej.

- Spośród biorących udział w referendum, osoby młode, kobiety oraz niepracujący głosowali w większości na 'Nie', większość pracowników wysokowykwalifikowanych, na stanowiskach kierowniczych oraz osób emerytowanych, głosowało na 'Tak'.

- Większość przeciwników Traktatu było przekonanych, że jego odrzucenie postawi Irlandię w silnej pozycji do renegocjacji dokumentu, umożliwi Irlandii zachowanie statusu neutralności oraz zapewni dalsze funkcjonowanie rozwiązań podatkowych w niezmienionym kształcie.

\footnotetext{
${ }^{2}$ Flash Eurobarometer, op. cit., s. 9.
} 
- Znaczna większość głosujących (68\%) wskazała, że kampania na 'Nie’ była bardziej przekonująca, co charakterystyczne, także większość głosujących na 'Tak' podzieliła tę opinię $(57 \%)$.

- W obozie głosujących na 'Tak' było więcej osób, które zmieniły zdanie, pierwotnie będąc w obozie na 'Nie' (25\%), w odwrotnej sytuacji tj. przejścia z opcji ‘Tak' na 'Nie' było $17 \%$ głosujących.

\section{Konsekwencje referendum}

Respondenci zostali zapytani o opinię jakie będą konsekwencje odrzucenia Traktatu Lizbońskiego w referendum. Uzyskane odpowiedzi zostały sklasyfikowane w trzech obszarach: obszarze UE, polityki wewnętrznej oraz kwestii związanych z zachowaniem tożsamości kraju.

- Obszar UE:

- 76\% głosujących przeciwko Traktatowi wyraziło opinię, że jego odrzucenie umożliwi irlandzkiemu rządowi wynegocjowanie wyłączeń (ang. opt-out) z dokumentu. Podobne stanowisko podzieliło 38\% głosujących na 'Tak';

- 33\% głosujących na 'Tak' i 33\% głosujących na 'Nie' wskazało, że w konsekwencji odrzucenia referendum instytucje europejskie zostaną ograniczone w swych działaniach;

- 52\% głosujących na 'Nie' oraz 48\% głosujących na 'Tak' wskazało, że umożliwi to zablokowanie działań prowadzących do stworzenia bardziej federalnej Europy;

- 64\% głosujących na 'Tak' wyraziło obawę, że pozycja Irlandii w Unii Europejskiej ulegnie osłabieniu. Podobne stanowisko wyraziło $24 \%$ głosujących na 'Nie';

- zwolennicy obu obozów kategorycznie zanegowali możliwość, że odrzucenie Traktatu jest jednoznaczne z wejściem Irlandii na drogę wystąpienia z Unii Europejskiej ( $88,5 \%$ grupy na 'Nie' oraz $89 \%$ na 'Tak');

- 39\% osób, które zagłosowały na 'Nie' wyraziło przekonanie, że rezultat referendum umocni pozycję Irlandii w Unii Europejskiej, podobnego zdania było 19\% głosujących na 'Tak'.

- Sprawy wewnętrzne:

- połowa głosujących na 'Tak' wyraziła przekonanie, że rezultat referendum wpłynie negatywnie na gospodarkę, z głosujących na 'Nie' podobne obawy podkreśliło $17 \%$ respondentów;

- 25\% głosujących na 'Nie' oraz 9\% głosujących na ‘Tak' wskazało, że rezultat referendum powinien zobowiązać rząd do ustapienia.

- Zachowanie tożsamości kraju:

- $83 \%$ głosujących na 'Nie' wyraziło stanowisko, że rezultat referendum zapewnia Irlandii neutralność; podobną opinię wyraziło $51 \%$ głosujących na 'Tak';

- 79\% głosujących na 'Nie' wskazało, iż odrzucenie Traktatu umożliwi zachowanie systemu podatkowego w niezmienionym kształcie. 50\% głosujących na 'Tak' podzieliło ten punkt widzenia ${ }^{3}$.

3 Flash Eurobarometer, op. cit., s. 10-11. 


\section{Raport Post Lisbon Treaty Referendum Research Findings, przygotowany przez Millward Brown IMS}

Ministerstwo Spraw Zagranicznych Irlandii opublikowało 10 września 2008 roku raport analizujący przyczyny i podłoże decyzji Irlandczyków w kwestii Traktatu Lizbońskiego i jego odrzucenia 12 czerwca. Raport opracowany został na zamówienie irlandzkiego MSZ przez niezależną firmę konsultingowo-badawczą Millward Brown $I M S$. Koszt realizacji tego zlecenia wyniósł 163 tysiące Euro. Badania przeprowadzono w okresie 24-31 lipca 2008 roku na grupie 2101 obywateli w całej Irlandii. Wyniki raportu rozczarowały tych, którzy oczekiwali, iż pojawią się jakieś nieznane, nowe, elementy obrazujące sytuację w dniu referendum. Potwierdziły się wszystkie ustalenia, które wcześniej przyniosły badania opinii publicznej dokonywane tuż po 12 czerwca, w tym przede wszystkim szeroko przytaczany powyżej raport przedstawicielstwa Komisji Europejskiej w Irlandii. Raport Millward Brown IMS jest dokumentem szerszym aniżeli raport przygotowany na zlecenie Komisji Europejskiej, jednakże dla zachowania przejrzystości niniejszego opracowania autor ograniczył jego analizę do przytoczenia najważniejszych w jego ocenie wniosków płynących z lektury tego dokumentu.

Z raportu Millward Brown IMS wynika, iż zdecydowana większość obywateli Irlandii jest zadowolona z dotychczasowego członkostwa w Unii Europejskiej i pragnie pozostania w niej ich kraju (ponad 70\% badanych uznało, ze członkostwo w Unii Europejskiej jest dobre dla Irlandii, zaledwie $8 \%$ było przeciwnego zdania $)^{4}$. Podstawowym czynnikiem skłaniającym do głosowania przeciw Traktatowi w czerwcu 2008 roku był natomiast brak wiedzy lub informacji o jego treści. Prawie 40\% biorących udział w głosowaniu podjęło decyzję w ciągu ostatniego tygodnia przed referendum, co wskazywać może na sporą niepewność i niedoinformowanie wśród elektoratu ${ }^{5}$. Pozostałe przyczyny głosowania przeciw Traktatowi były według raportu bardzo różnorodne: skład Komisji Europejskiej i ryzyko utraty komisarza, kwestie podatkowe, prawa pracownicze, neutralność, obawa przed powołaniami do armii europejskiej i ograniczeniem niepodległości, aborcja i inne. Żadna z tych przyczyn nie była szczególnie dominująca. W podziale według grup wiekowych najbardziej przeciwne Traktatowi były osoby w wieku $25-34$ (około $60 \%$ osób z tej grupy wiekowej głosowało przeciw) ${ }^{6}$.

Badanie zweryfikowało także nastawienie głosujących, określając stopień przekonania co do podjętej decyzji - w związku z tym głosy zostały sklasyfikowane jako tzw. „twarde” i „miękkie”, co wskazuje jaka część obu grup potencjalnie może zostać nakłoniona do zmiany decyzji w przyszłości. Z głosujących na 'Tak', 36\% zostało sklasyfikowane jako głosy „twarde”, czyli zdecydowanie przekonani o zasadności wprowadzenia Traktatu w życie. 10\% spośród głosujących na “Tak’ to głosy „miękkie”. 41\%

${ }^{4}$ Post Lisbon Treaty Referendum Research Findings, Millward Brown IMS, September 2008, s. 19 .

5 Dane procentowe w tym zakresie różnią się w obu raportach, niemniej wskazująjednoznacznie na niezdecydowanie znacznej części głosujących.

${ }^{6}$ Post Lisbon Treaty Referendum Research Findings, Millward Brown IMS, September 2008, s. 5. 
głosujących na 'Nie' to głosy „twarde”, głosy miękkie opcji na 'Nie' to $13 \%$. 76\% głosujących na 'Nie' w odpowiedzi na pytanie o to na ile pewni byli podejmując decyzję wskazało, że byli ,zdecydowanie przekonani”. 24\% wskazało natomiast na pewne wątpliwości - nie było zatem w pełni przekonanych co do podjętej decyzji - do tej ostatniej grupy będzie najprawdopodobniej odwoływała się strona rządowa w przypadku decyzji o kolejnym referendum. Istnieje bowiem realna możliwość, że w przypadku określonych zmian i ustępstw w zakresie treści dokumentu uda się tą część elektoratu przekonać do zmiany zdania i poparcia Traktatu.

Raport Millward Brown IMS ma być, według założeń rządu, podstawowym materiałem do dalszych przemyśleń w kwestii sformułowania odpowiedzi na pytanie co leżało u podstaw decyzji obywateli: uczestniczyć w referendum lub nie, głosować przeciw lub za Traktatem. Analiza raportu ma być pomocna przy ustaleniu dalszej drogi postępowania i to nie tylko w wymiarze irlandzkim - wnioski z raportu i opisy nastrojów i obaw społecznych odzwierciedlać bowiem mogą nastroje w całej Unii Europejskiej. Raport został zaprezentowany przez premiera Briana Cowena na forum Rady Europejskiej w październiku 2008 roku, jednak zgodnie z oczekiwaniami, prezentacji wyników nie towarzyszyły konkretne propozycje dalszych działań irlandzkiego rządu w kontekście wyjścia z kryzysu ratyfikacyjnego. Za pozytywną informację dla koalicji rządowej można uznać fakt, iż 60\% respondowanych wyraziło przekonanie, że najlepszym sposobem zabezpieczenia interesów Irlandii jest pełne zaangażowanie w działania Unii Europejskiej. Stoi to jednak w oczywistej sprzeczności z wynikiem referendum ${ }^{7}$.

\section{Stanowisko irlandzkiego rządu}

W celu określenia scenariuszy dalszego postępowania w kontekście Traktatu Lizbońskiego należy odwołać się do retoryki irlandzkiego rządu. Premier Irlandii, Brian Cowen, przyznał we wrześniu 2008 roku, że strona rządowa poczyniła błędy w kampanii dotyczącej Traktatu. W wywiadzie telewizyjnym wskazał: „Obywatele dokonali wyboru. Gdybym musiał powiedzieć czy inaczej prowadziłbym kampanię obecnie, odpowiedź brzmi: Tak". Dodał jednocześnie, że jego rząd musi obecnie zmierzyć się z konsekwencją referendum i obywatele zdają sobie stopniowo sprawę, że nie można tego zrobić w krótkim czasie ${ }^{8}$. Już po ogłoszeniu wyników przytaczanego powyżej raportu Millward Brown IMS, minister spraw zagranicznych Irlandii, Michael Martin, zaznaczył, iż wyniki prac zespołu badawczego pozwalają zrozumieć motywacje obywateli oraz, że obowiązkiem polityków jest respektować decyzje wyborcze i głęboko zastanowić się nad przesłaniem, jakie płynie z czerwcowego niepowodzenia. Ogłosił także, że dla dalszych dokładnych analiz i pogłębienia dialogu społecznego powstanie w ramach parlamentarnej Komisji do Spraw Europejskich parlamentu specjalna podkomisja, w skład której wejdą przedstawiciele wszystkich ugrupowań politycznych.

7 S. Collins, Failure to inform voters doomed Lisbon, „The Irish Times”, 11.09.2008, s. 7.

8 M. Hennessy, Cowen accepts mistakes were made over Lisbon Treaty, „The Irish Times”, 6.09.2008, s. 9. 
Komisja miałaby w jego opinii objać swymi badaniami szerokie spektrum polityczne oraz społeczne zarówno wśród zwolenników, jak i przeciwników Traktatu. Plan, by powołać komisję parlamentarną badająca przyczyny „Nie” został jednak odrzucony przez opozycyjne partie: Fine Gael i Partię Pracy i jak na razie nie zostanie zrealizowany. Powstał tym samym rodzaj impasu politycznego w kwestii co należy robić dalej, szukając rozwiązania dla zaistniałej sytuacji. minister spraw zagranicznych, Michael Martin, omówił na forum gabinetu szczegóły obu opublikowanych raportów. W jego opinii, należy zwrócić uwagę na fakt, że relatywnie duże obawy obywateli dotyczyły wcielenia Irlandczyków do struktur wojskowych Unii Europejskiej. Dla wielu z nich Traktat Lizboński był równoznaczny z obowiązkową służbą wojskową. Pozytywnym przesłaniem obu raportów w ocenie ministra Michaela Martina jest wniosek, że ogólny stosunek obywateli Irlandii do członkostwa w Unii Europejskiej jest wciąż pozytywny i że obywatele chcą by Irlandia była w centrum Europy9.

Wykres 3. Pozytywne postrzeganie czlonkostwa w UE przez obywateli poszczególnych krajów

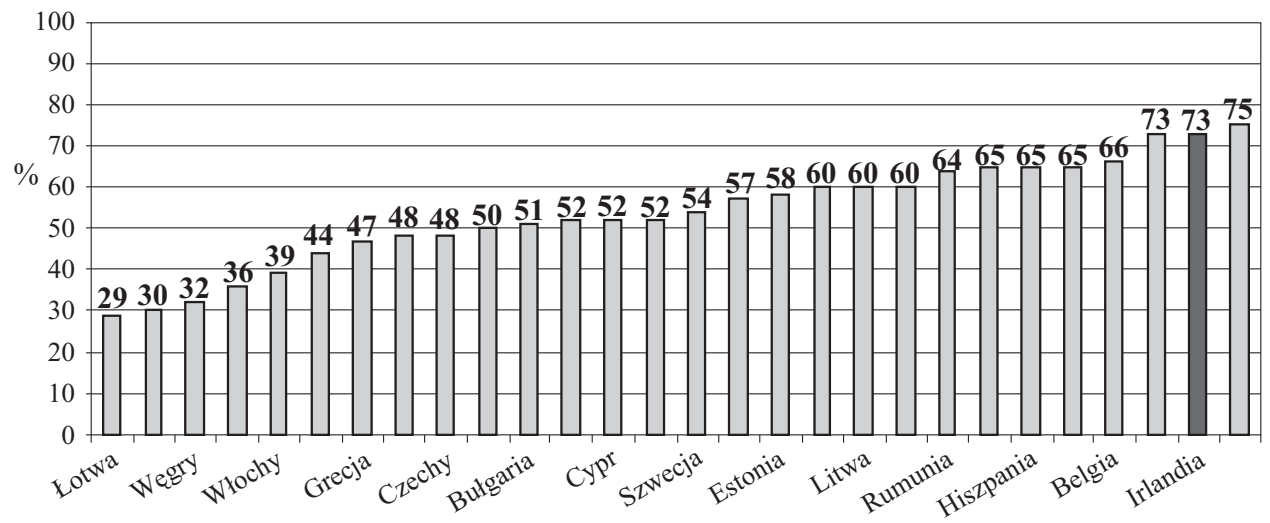

Źródło: Post Lisbon Treaty Referendum Findings, Millward Brown IMS, September 2008, s. 19.

Rząd irlandzki powtarza konsekwentnie, że potrzebny jest znacznie dłuższy niż pierwotnie przewidywano czas refleksji, iż trzeba dogłębnie poznać przyczyny porażki z 12 czerwca 2008 roku, że nie stać Irlandii i Unii Europejskiej na podjęcie pochopnej decyzji. Według rządu irlandzkiego potrzebna jest szeroka narodowa dyskusja na temat przynależności Irlandii do Unii Europejskiej, na temat miejsca Irlandii w międzynarodowym unijnym otoczeniu by odpowiedzieć sobie na pytanie jak realizować narodowe interesy, a zarazem pozostawać w głównym nurcie polityki europejskiej. Opublikowane dotychczas raporty dopiero tę dyskusję inicjują ${ }^{10}$. Większość partii na irlandzkiej scenie politycznej jest także zgodnych, że potrzebny jest czas na analizę raportów, nie wykluczają przy tym kolejnych badań, po których będzie można przystapić do wyciągania wniosków i opracowania propozycji przyszłościowych. Dla przykładu, Lider s. 14

9 S. Collins, Research on rejection of Lisbon Treaty published, „The Irish Times”, 10.09.2008,

10 E. Regan, Finding a way out of the Lisbon deadlock, „The Irish Times”, 10.09.2008, s. 18. 
Partii Pracy - Eamon Gilmore - zaznaczył, że na chwilę obecną nie należy podejmować decyzji o ewentualnym ponownym referendum. Byłoby ono uzasadnione jego zdaniem w sytuacji gdyby doszło do radykalnej zmiany oceny opinii publicznej lub pod głosowanie poddany zostałby całkowicie inny dokument. Przytoczył przy tym przeprowadzone we wrześniu 2008 roku badanie, które potwierdziło, że gdyby referendum zostało powtórzone, 52\% zapytanych głosowałoby na „Nie”, a zaledwie 32\% głosujących poparłoby dokument w jego niezmienionej formule ${ }^{11}$.

Niezależnie od oficjalnych deklaracji o wejściu w okres refleksji nad Traktatem, irlandzki rząd stara się wpływać na opinię publiczną, przygotowując ją niejako do realizacji scenariusza ponownego referendum. Używa przy tym retoryki, która wskazuje na powiązanie faktu odrzucenia referendum z aktualną kondycją makroekonomiczną kraju. W oświadczeniach ministrów pojawiają się ostrzeżenia przed gospodarczymi konsekwencjami, jakie może ze sobą nieść nierozwiązany „lizboński dylemat”. Dał temu wyraz minister spraw zagranicznych, Michael Martin, który wskazał, że spodziewa się, iż plany rozwiązania impasu zostaną podane pod koniec 2008 roku. Dodał, że przyszłość Irlandii w sercu Europy jest nierozerwalnie związana z przyszłością jej gospodarki, podkreślając znaczenie irlandzkiej pozycji w Unii Europejskiej w świetle obecnej sytuacji gospodarczej. Zaprzeczył jednak jakoby łączenie gospodarki i Traktatu miało na celu przekonanie wyborców do głosowania na ,Tak” w drugim referendum konkludując: „Ogromna część naszego handlu opiera się na krajach członkowskich Unii. Najważniejsze zewnętrzne więzi, jakie mamy, to więzi z tymi krajami"12.

Przy okazji publikacji budżetu na 2009 rok (październik 2008), także premier Brian Cowen odwołał się do kwestii Traktatu Lizbońskiego i sytuacji gospodarczej. Zaznaczył, że wydatki rządowe w budżecie na 2009 rok mają zostać znacznie ograniczone. Dodał, iż obecna sytuacja gospodarcza sprawia, że problemów nie da się rozwiązać w łatwy sposób. Odwołując się do wyniku referendum, podkreślił, iż irlandzcy wyborcy nie powinni utrudniać dodatkowo sytuacji kraju: „Staje się dla mnie jasne, że nasze problemy gospodarcze oraz dylematy natury politycznej są połączone. Nie zdołaliśmy odpowiedzieć na wątpliwości części obywateli i dotrzeć z informacją, że odrzucenie Traktatu Lizbońskiego może pogorszyć już trudną sytuację gospodarczą w jakiej się znaleźliśmy. Musimy sprostać tym błędom, przekonując większą ilość obywateli do faktu, że imperatywem dla Irlandii powinna być ścisła współpraca z naszymi partnerami w Unii Europejskiej"'13.

Podobne do cytowanych powyżej opinie wygłaszane przez liderów politycznych wskazują na chęć przygotowania opinii publicznej do drugiego referendum. Irlandzki premier i ministrowie zaczęli wykorzystywać do tego celu hasła bardziej jednoznaczne aniżeli miało to miejsce przed czerwcem 2008 roku $^{14}$.

${ }^{11}$ H. McGee, B. Roche, Opposition invited to discuss Lisbon No, „The Irish Times”, 28.07.2008, s. 17.

12 M. Regan, Martin: Unresolved Lisbon threatens economy, „Irish Examiner”, 16.09.2008, s. 8.

13 M. Hennessy, Taoiseach signals big budget cuts inevitable, „The Irish Times”, 16.09.2008, s. 1 .

14 B. O'Halloran, Business groups lend support to Yes vote, „The Irish Times”, 2.05.2008, s. 8. 


\section{Odrzucenie Traktatu Lizbońskiego a stanowisko Wielkiej Brytanii i Francji}

W czasie wizyty 11 września 2008 roku w Dublinie, minister spraw zagranicznych Wielkiej Brytanii, David Milliband, pozytywnie ocenił reakcję irlandzkiego rządu na fiasko referendum. Nie wszystkie kraje członkowskie podzieliły jednak opinię brytyjskiego ministra. Rozbieżne reakcje partnerów europejskich podkreśliły zmianę pozycji Irlandii w Unii Europejskiej. Tradycyjnie eurosceptyczni Brytyjczycy wskazali, że Irlandia nie powinna być piętnowana, podczas gdy jej tradycyjni sojusznicy - Francuzi i Niemcy - zaczęli wykazywać zniecierpliwienie w związku z impasem wywołanym referendum. Stanowisko Wielkiej Brytanii może być postrzegane jako dowód dojrzałych, przyjacielskich relacjach między sąsiadującymi krajami, jakkolwiek należy mieć na uwadze, że w długoterminowej perspektywie, Brytyjczykom zależy na wyłączeniu Irlandii z bezpośredniego zakresu oddziaływania Francji i Niemiec. Kraje członkowskie Unii Europejskiej chętnie widziałyby rozwiązanie irlandzkiego problemu związanego z Traktatem przed wyborami do Parlamentu Europejskiego w czerwcu 2009 roku oraz wyborem nowej Komisji Europejskiej jesienią 2009 roku. Francuscy politycy z otoczenia prezydenta Nicolasa Sarkozy'ego podkreślili, że oczekuje się od Irlandii więcej aniżeli tylko analizy badań dotyczących fiaska referendum. Prezydent Francji, Nicolas Narkozy, zwrócił się do ekspertów prawnych Rady Europejskiej z prośbą o ścisłą współpracę z irlandzkim rządem w kontekście Traktatu. W odpowiedzi, premier Irlandii, B. Cowen, wskazał w październiku 2008 roku, że eksperci prawni UE już współpracują z rządem irlandzkim w zakresie obszarów tematycznych, które budziły wątpliwości wśród głosujących. Prezydent Nicolas Sarkozy, zadeklarował, że odwiedzi raz jeszcze Irlandię w grudniu 2008 roku przed spotkaniem Rady Europejskiej (wcześniej przybył z wizytą do Irlandii w lipcu 2008 roku). Wyraził oczekiwanie, że przy tej okazji premier Irlandii, Brian Owen, nakreśli dalszy plan postępowania z Traktatem ${ }^{15}$.

\section{Komentarze irlandzkich mediów dotyczące referendum}

Media w Irlandii podkreśliły fakt, że rząd przyznał się oficjalnie, iż kampania przedreferendalna prowadzona przez obóz zwolenników Traktatu była nieefektywna i nieskuteczna. Analitycy i obserwatorzy politycznej sceny w Irlandii zgodni są w opinii, iż rząd, mając świadomość stanu nastrojów obywateli oraz utrzymującego się wyraźnego sceptycyzmu wobec Traktatu, stara się maksymalnie odsunąć moment podjęcia decyzji dotyczącej dalszego postępowania ratyfikacyjnego. Nadal sprawą otwartą pozostają zakres i termin ewentualnego drugiego referendum. Próby przyspieszenia wyboru daty w postaci wywierania presji ze strony partnerów europejskich przynoszą jak dotąd $\mathrm{w}$ ocenie mediów efekt sprzeczny z oczekiwanym ${ }^{16}$.

15 J. Smyth, Government to explore Lisbon opt-outs with EU legal service, „The Irish Times”, 17.10.2008, s.1.

${ }_{16}$ M. Hennessy, J. Smyth, State may consider EU defence opt-out to pass Lisbon Treaty, „The Irish Times", 8.09.2008, s. 1. 
Jako możliwy scenariusz wyjścia z sytuacji wysuwana jest przez komentatorów politycznych między innymi: idea dalszych negocjacji z UE o ewentualnych odstępstwach od pierwotnej treści dokumentu lub zmiana konstytucji. Referendum mogłoby dotyczyć tylko zmian w treści ustawy zasadniczej. Parlament Irlandii (Dail) ma bowiem prawo ratyfikować traktat, jeśli nie jest on sprzeczny z ustawą zasadniczą. Część komentatorów sugeruje, iż należałoby wyszczególnić te części Traktatu, które dotyczyłyby spraw konstytucyjnych. Następnie wyszczególnione kwestie - w formie konkretnych pytań - powinny zostać poddane narodowemu głosowaniu. Nie byłoby wtedy konieczne głosowanie nad liczącym kilkaset stron tekstem, z którym nie zapoznali się nawet jego orędownicy w postaci irlandzkiego komisarza do spraw rynku wewnętrznego w Unii Europejskiej, Charlie McCreevy'ego ${ }^{17}$. Prasa sugeruje także scenariusz, w którym w przypadku gdy określone kwestie sporne nie uzyskają poparcia społecznego, parlament może negocjować nowe rozwiązania i ratyfikować tylko część Traktatu, pomijając kwestie sporne. W praktyce parlament (Dail) mógłby podjąć kolejne próby ratyfikacji pozostałych części dokumentu w okresie późniejszym. W ten sposób Irlandia pozostałaby pełnoprawnym członkiem Unii Europejskiej, respektując jednocześnie zdanie społeczeństwa. Ustrzegłoby to też Irlandię przed dyplomatycznym koszmarem ciagłego blokowania unijnych reform. W przypadku powielenia pytania na zasadzie „Tak-Nie” szanse na ratyfikację dokumentu są znikome. Inną - skrajną - opcją, także wysuwana przez media, byłoby pytanie do elektoratu o chęć pozostania Irlandii w strukturze Unii Europejskiej ${ }^{18}$.

Irlandzka prasa posuwa się tak dalece, iż stawia pytanie o to czy w perspektywie kilku lat Irlandia będzie wciąż pełnoprawnym członkiem Unii Europejskiej. Sugestie, że taki scenariusz byłby możliwy są jednak jak na razie marginalizowane. Podnoszony jest jednak argument wskazujący, że jeśli w kolejnym referendum Traktat zostanie ponownie odrzucony, Irlandia będzie musiała liczyć się z marginalizacją. Opiniotwórczy dziennik „Irish Times” wydaje się podzielać opinie części polityków Unii Europejskiej wskazując, że jeden kraj nie powinien dyktować pozostałym 26 co mają robić, a naród w liczbie 4 milionów nie może blokować 500 milionów obywateli Unii Europejskiej. Część publicystów sugeruje, że mieszkańcy Irlandii są nieświadomi twardych realiów prawdziwej polityki. Wskazuje przy tym, że 56\% Irlandczyków wierzy, że irlandzkie wpływy w Unii Europejskiej wzmocniły się bądź nie zmieniły po referendum. W praktyce natomiast, przywódcy Unii Europejskiej postrzegają teraz Irlandię jako kraj, który uzyskał od Wspólnot miliardy Euro, nie dając nic w zamian ${ }^{19}$. Dodatkowo, irlandzki rząd i dyplomacja skutecznie chronią wyborców od prawdy, utwierdzając ich w błędnym przekonaniu, że Irlandia nie poniesie żadnych konsekwencji swojej decyzji. „The Sunday Tribune" wskazuje, że kraje Unii Europejskiej konkurujące z Irlandią o zagraniczne inwestycje, zyskują przewagę. W ocenie tygodnika, choć badania opinii społecznej pokazują, że Irlandczycy cenią członkostwo w UE, to należy ich uświadomić,

17 Forum, na podstawie The Guardian, „International Herald Tribune”, 16.06-22.06.2008, s. 7.

18 S. Collins, Nuclear option may be best tactic for ratifying treaty, 13.09.2008, witryna internetowa: www.irishtimes.com.

${ }_{19}$ Od wstapienia Irlandii do Europejskiej Wspólnoty Gospodarczej w 1973 roku kraj ten otrzymał dotacje w kwocie sięgającej 40 miliardów Euro. 
że nie jest to sytuacja gwarantowana niezależnie od okoliczności ${ }^{20}$. Prasa w Irlandii zasugerowała także, iż plan mający na celu izolację Irlandii i nakłonienie jej do przeprowadzenia drugiego referendum przed marcem 2009 roku był dyskutowany w trakcie szczytu Unii Europejskiej w październiku 2008 roku. „The Sunday Times” podkreślił, że część francuskich polityków oraz członków Parlamentu Europejskiego wskazała, iż Irlandia powinna zostać pośrednio zmobilizowana do działania, to jest poprzez naciski na Polskę i Czechy, aby kraje te ratyfikowały Traktat przed grudniem 2008 roku $^{21}$.

\section{Podsumowanie}

Badania opinii publicznej wykonane w okresie bezpośrednio po referendum nie ukazują jednej z podstawowych przyczyn jego niepowodzenia. Jego data zbiegła się w czasie z osłabieniem kondycji gospodarki światowej, co odbiło się bezpośrednio na koniunkturze w Irlandii. Nastroje społeczne uległy pogorszeniu, doszło do korekty cen na rynku nieruchomości, wzrosło bezrobocie, a nastroje społeczne uległy zdecydowanemu pogorszeniu. Na ten podatny grunt trafiły proste hasła ugrupowań nacjonalistycznych, które choć obiektywnie nie miały wiele wspólnego z Traktatem, to okazały się nadspodziewanie skuteczne. Pogorszenie sytuacji gospodarczej kraju wyeksponowało jeszcze jeden problem trapiący Irlandię - legendarny już sukces Celtyckiego Tygrysa zaowocował wzrostem zamożności większości obywateli, ale także spowodował rozwarstwienie społeczne i wywołał wśród najsłabiej zarabiających poczucie alienacji. To ostatnie zostało dodatkowo wzmocnione przez konkurencję na rynku pracy, która ze względu na napływ pracowników z Europy Środkowo-schodniej po 1 maja 2004 roku, sukcesywnie rosła. Rząd irlandzki nie ma ściśle określonego scenariusza, który miałby umożliwić mu wyjście z impasu. W opinii autora, Irlandia podejmie się przeprowadzenia ponownego referendum. Trzeci lub czwarty kwartał 2009 roku wymieniany jest jako jego możliwy termin. Presja ze strony części parterów w Unii Europejskiej, na czele z Francją, pozwala przypuszczać, że ogłoszenie drugiego referendum nad Traktatem Lizbońskim jest w istocie kwestią czasu. Rząd irlandzki odżegnuje się jednak konsekwentnie od jakichkolwiek deklaracji w tej kwestii. Takie postępowanie podyktowane jest gorszą sytuacją gospodarczo-społeczną kraju aniżeli miało to miejsce w czerwcu 2008 roku. Można tym samym praktycznie wykluczyć sytuację, w której pod głosowanie poddany zostałby dokument w niezmienionej formie. Najprawdopodobniej, Irlandia uzyska możliwość odstąpienia od części rozwiązań (ang. opt-out), dodatkowo uzyskując gwarancję obsadzania przez jej obywatela stanowiska komisarza w Komisji Unii Europejskiej. Można także przyjąć założenie, że premier Brian Cowen podejmie ryzyko kolejnego referendum tylko w sytuacji, gdy badania opinii publicznej dadzą znaczny stopień pewności, iż jego wynik będzie pozytywny. W irlandzkiej prasie

20 S. Coleman, Voters must wake up to reality of Lisbon, „The Sunday Tribune”, 14.09.2008, s. 5.

21 Alain Lamassoure, francuski członek PE, wskazał, że Irlandczycy powinni zostać poinformowani o konsekwencjach ewentualnego ponownego odrzucenia referendum. Nie sprecyzował jak takie konsekwencje miałyby wyglądać. R. Oakley, Revealed: EU plans to force new Lisbon vote, „, The Sunday Times", 19.10.2008, s. 1. 
pojawiają się sugestie, że być może właściwą polityką w kontekście ewentualnego kolejnego referendum w sprawie Traktatu powinno być ograniczenie kwestionariusza do odpowiedzi: "Tak" lub "Nie" na pytanie o chęć pozostania kraju w UE. Takie uproszczenie miałoby w zamyśle pomóc przeforsowaniu dokumentu. Publicyści podkreślają każdorazowo, że może to być skuteczna, lecz bardzo ryzykowna strategia. Rząd jak na razie nie odwołuje się do tej koncepcji. Premier Brian Cowen zbiera odium niezadowolenia wynikającego z faktu, że jako były minister finansów jest obarczany winą za niepodejmowanie odpowiednio wcześnie decyzji, które miałyby uchronić Irlandię przed kryzysem. Kolejne referendum przybierze w związku z tym także formę głosowania nad publicznym wotum zaufania wobec rządu. Ewentualne ponowne odrzucenie Traktatu Lizbońskiego będzie w związku z tym równoznaczne z ustąpieniem rządzącej koalicji (Fianna Fail - Zieloni) i rozpisaniem przedterminowych wyborów. 
